\title{
PENGARUH PEMBERIAN KREDIT USAHA RAKYAT (KUR) TERHADAP PERKEMBANGAN UMKM DI KOTA JAYAPURA (STUDI KASUS PADA BANK PAPUA KANTOR CABANG UTAMA JAYAPURA)
}

\author{
Markus Setiawan Soumokil \\ Universitas Cenderawasih \\ email: markussetiawansoumokil13@gmail.com
}

\begin{abstract}
The purpose of this study is to find out and analyze the influence of people's business credit (KUR) on the development of MSMEs in Jayapura City. This research uses qualitative method with descriptive approach. The results showed that the government provides access to people's business credit or often known as KUR through banking institutions that currently play a very good role. The granting of People's Business Credit (KUR) has a partial significant effect on the development of small and mediumsized micro enterprises in jayapura.
\end{abstract}

Keywords: people's business credit; MSMEs; bank

\begin{abstract}
Abstrak
Tujuan penelitian ini adalah untuk mengetahui dan menganalisis pengaruh pemberian kredit usaha rakyat (KUR) terhadap perkembangan UMKM di Kota Jayapura. Penelitian ini menggunakan metode kualitatif dengan pendekatan deskriptif. Hasil penelitian menunjukkan bahwa pemerintah memberikan akses kredit usaha rakyat atau sering dikenal dengan KUR tersebut melalui lembaga perbankan yang pada saat ini sangatlah berperan baik. Pemberian Kredit Usaha Rakyat (KUR) berpengaruh signifikan secara parsial terhadap Perkembangan Usaha Mikro Kecil dan Menengah di kota Jayapura.
\end{abstract}

Kata Kunci: kredit usaha rakyat; UMKM; bank

\section{Pendahuluan}

Krisis yang menimpa Indonesia tahun 1997 diawali dengan krisis nilai tukar rupiah terhadap dollar Amerika Serikat dan krisis moneter yang berdampak pada perekonomian Indonesia yakni resesi ekonomi. Hal ini 
merupakan pelajaran yang sangat penting untuk kembali mencermati suatu pembangunan ekonomi yang benar-benar memiliki struktur yang kuat dan dapat bertahan dalam situasi apapun (Anggraini \& Nasution, 2013).

Pemberdayaan UMKM (Usaha Mikro Kecil Menengah) di tengah arus globalisasi dan tingginya persaingan membuat UMKM harus mampu mengadapai tantangan global (Sedyastuti, 2018). Usaha mikro, kecil dan menengah telah menjadi isu yang menarik untuk dicermati dan disikapi, menurut (Wahyuni, Eti, 2005) hal ini dikarenakan ada beberapa alasan antara lain saat krisis sektor UMKM dapat bertahan sampai saat ini, perhatian pemerintah terhadap UMKM masih kurang, sektor UMKM yang jumlahnya cukup banyak sangat potensial dalam menyerap tenaga kerja, sektor UMKM memiliki peran penting dan kontribusinya cukup besar dalam struktur perekonomian nasional. (Arliman, 2017) Usaha Mikro Kecil dan Menengah (UMKM) memiliki peran strategis dalam memperkokoh perekonomian rakyat secara nasional

Peranan perbankan sangat mempengaruhi kegiatan ekonomi suatu negara (Hamidu, 2013). Perbankan sebagai suatu lembaga keuangan kepercayaan masyarakat yang memegang peranan penting dalam sistem perekonomian, sehingga dapat dikatakan bank merupakan urat nadi dari sistem keuangan yang beraktifitas menerima simpanan dari masyarakat dalam bentuk tabungan, giro, deposito dll, yang kemudian dana yang terkumpul dari masyarakat tersebut disalurkan kembali ke masyarakat dalam bentuk kredit.

Salah satu kegiatan bank yang sangat penting dan utama adalah menyalurkan kredit kepada masyarakat, baik kredit perorangan maupun kredit lembaga atau kredit perusahaan, sehingga pendapatan bank dari kredit yang berupa bunga merupakan sumber utama pendapatan bank. Bila diperhatikan neraca bank akan terlihat bahwa sisi aktiva bank akan didominasi oleh besarnya jumlah kredit.

Bank Pembangunan Daerah (BPD) Papua masuk dalam daftar perbankan yang ikut menyalurkan KUR. Selain menyalurkan KUR, Bank Papua juga memiliki dua program kredit, yakni Pinjaman Usaha Mikro (PUM) dan kredit peduli Papua. Khusus kredit peduli Papua, sasarannya adalah pelaku usaha penduduk asli dengan bunga kredit 10\% namun demikian, pemerintah daerah tidak selalu sesuai dengan upaya pengembangan UKM. Misalnya, birokrasi perizinan Usaha Mikro Kecil dan Menengah (UMKM) masih menjadi persoalan utama yang menghambat pertumbuhan usaha kecil di daerah sehingga membuat mayoritas pelakunya tidak memiliki status hukum seperti dipaparkan Direktur UKM Center Universitas Indonesia Nining I. Soesilo.

Sektor usaha kecil atau UKM banyak dikembangkan di daerah perkotaan termasuk juga di Kota Jayapura. Kota Jayapura merupakan ibukota Provinsi Papua. Kota ini berada di kawasan Teluk Humbolt atau Yos Sudarso di bagian 
utara Provinsi Papua. Lokasi ini menempatkan Kota Jayapura pada posisi yang strategis, terutama sebagai pintu gerbang bagi kabupaten-kabupaten dan distrik-distrik di Provinsi Papua. Kota Jayapura berpotensi menjadi salah satu simpul koleksi distribusi barang dan jasa nasional ditunjang oleh sumber daya yang memadai dan menjadikan Provinsi Papua yang baik.

Pemberian KUR terhadap perkembangan UMKM di Kota Jayapura dapat dilihat pada tabel 1 dari tahun 2013-2018 sebagai berikut:

Tabel 1.

\begin{tabular}{ccc}
\hline Tahun & Outstanding Kredit & Presentase \\
\hline 2013 & 187.298 .313 .019 & $27 \%$ \\
\hline 2014 & 195.536 .029 .938 & $23 \%$ \\
\hline 2015 & 82.522 .158 .937 & $10 \%$ \\
\hline 2016 & 8.031 .146 .416 & $8 \%$ \\
\hline 2017 & 10.346 .653 .930 & $10 \%$ \\
\hline 2018 & 10.478 .621 .000 & $12 \%$ \\
\hline
\end{tabular}

Sumber : data diolah, 2019

Berdasarkan data penelitian di atas tabel perkembangan usaha mikro kecil dan menengah (UMKM) di Kota Jayapura periode 2016-2018, menjelaskan bahwa tahun 2016 outstanding kredit sebesar 8\% dan di tahun 2017 meningkat presentasenya sebesar $10 \%$ dan di tahun 2018 meningkat sebesar 12\% arti bahwa dengan adanya pemberian kredit perkembangan usaha mikro kecil dan menengah (UMKM) di Kota Jayapura mengalami perkembangan yang sangat pesat.

Kota Jayapura sebagai ibukota provinsi memiliki potensi yang sangat besar dalam upaya pengembangan UKM sebagai penunjang pertumbuhan Ekonomi Masyarakat, namun ada beberapa faktor yang merupakan fenomena dalam mempengaruhi pertumbuhan ekonomi di dunia Usaha Kecil dan Menengah yaitu (1). Kualitas SDM di bidang usaha kecil dan menengah masih rendah, (2). Tingkat kesejahteraan masyarakat lokal yang rendah, (3).Modal usaha kecil dan menengah yang tidak tersedia, (4). Kurangnya kebijakan pemerintah daerah terhadap pengembangan UKM, (5).Strategi pemasaran jenis barang/komoditi yang diusahakan tidak tersedia.

Kendala yang dihadapi dalam pelaksanaan penyaluran KUR oleh PT. Bank Pembangunan Daerah Papua adalah terbatasnya akses Sistem Informasi Debitur (SID), karena dibeberapa daerah masih terdapat jaringan komunikasi yang kurang bagus, kondisi geografis Papua yang relative sulit di jangkau, gambaran masyarakat bahwa KUR adalah bantuan kredit sehingga ada indikasi sengaja dimacetkan, kondisi sosial budaya masyarakat yang kadang menjadi 
penghambat berkembangnya bisnis UMKM, dimana faktor masyarakat masih sangat dominan.

Berdasarkan uraian latar belakang masalah di atas maka penulis bermaksud untuk melakukan penelitian dengan judul "Pengaruh Pemberian Kredit Usaha Rakyat (Kur) Terhadap Perkembangan UMKM Di Kota Jayapura (Studi Kasus Pada Bank Papua Kantor Cabang Utama Jayapura)".

Penulis meninjau beberapa penelitian terdahulu yang ada hubungannya dengan variabel Kredit Usaha Rakyat (KUR), dan variabel perkembangan UMKM. Dalam penelitian terdahulu akan diuraikan mulai dari nama tahun, judul penelitian, dan hasil penelitian terdahulu dengan penelitian yang penulis lakukan beberapa penelitian terdahulu yang penulis jadikan tinjauan adalah sebagai berikut.

Menurut (Supriyanto, 2006) Pemberdayaan Usaha Mikro Kecil dan Menengah (UMKM) sebagai salah satu upaya penanggulangan kemiskinan, menyimpulkan dalam penelitiannya ternyata UMKM mampu menjadi solusi penanggulangan kemiskinan di indonesia. Penanggulangan kemiskinan dengan cara mengembangkan UMKM memiliki potensi yang cukup baik, karena ternyata sektor UMKM memiliki kontribusi yang besar dalam penyerapan tenaga kerja, yaitu menyerap lebih dari 99,45\% tenaga kerja dan sumbangan terhadap PDB sekitar 30\%. Upaya untuk memajukan dan mengembangkan sektor UMKM dan akan dapat menyerap lebih banyak lagi tenaga kerja yang ada dan tentu saja akan dapat meningkatkan kesejahteraan para pekerja yang terlibat di dalamnya sehingga dapat mengurangi angka pengangguran.

Menurut (Saputro et al., 2010) Peta Rencana (ROADMAP) Riset Enterprise Resource Planning (ERP) dengan focus Riset pada Usaha Mikro Kecil dan Menengah (UMKM) di Indonesia melihat bahwa Usaha Kecil dan Menengah (UKM) di indonesia telah banyak memberikan kontribusi terhadap PDB (Produk Domestik Bruto) nasional sebesar 5.56\% berdasarkan data Biro Perencanaan Kementerian Negara Koperasi dan UKM Republik Indonesia, pada tahun 2008. Untuk memperluas pangsa pasar dan meningkatkan daya saing UKM, membutuhkan suatu aplikasi yang dapat mengintergrasikan dan mengotomatisasi proses bisnis UKM.

Menurut (Pratama Putra \& Setyadhi Mustika, 2012) melakukan pengamatan terhadap program yang di gulirkan oleh pemerintah melalui lembaga Jamkrida. Jamkrida memberikan jaminan kredit bagi UMKM dalam upaya membantu permodalan untuk kelangsungan dan pengembangan usaha dimasa yang akan datang. Tujuan penelitian untuk mengetahui efektivitas program Jaminan Kredit Daerah (jamkrida) di kabupaten tabanan, penyerapan tenaga kerja UMKM di Kabupaten Tabanan. Sampel penelitian ditentukan dengan rumus slovin sebanyak 76 UMKM. Alat analisis data dalam penelitian 
ini menggunakan analisis efektivitas dan uji beda, terdiri dari uji normalitas dan uji wilcoxon. Berdasarkan hasil pembahasan, maka dapat disimpulkan dari hasil penelitian adalah sebagai berikut pelaksanaan program jamkrida di kabupaten tabanan adalah sangat efektif terhadap pendapatan dan penyerapan tenaga kerja di Kabupaten Tabanan.

Penelitian terdahulu yang dilakukan oleh (Darwanto, 2013) melakukan penelitian terhadap pertumbuhan UMKM dalam perekonomian di indonesia. UMKM sebagai bagian dari perekonomian juga harus sering meningkatkan daya saing dengan melakukan inovasi. Keunggulan bersaing berbasis inovasi dan kreativitas harus lebih di utamakan karena mempunyai daya tahan dan jangka waktu lebih panjang. Penelitian ini bertujuan merumuskan strategi kelembagaan dalam mendorong inovasi dan kreativitas pelaku UMKM. Adapun peneliti melakukan penelitian ini hanya dengan satu wilayah spesifik untuk menjadi gambaran atau contoh dari wajah umkm yang ada di Indonesia.

\section{Metode Penelitian}

Penelitian ini menggunakan metode kualitatif dengan pendekatan deskriptif. Dalam analisis deskriptif, data yang telah terkumpul melalui angket akan diolah dengan cara diskor hasil yang di capai oleh masing-masing responden untuk memudahkan proses analisis. Berdasarkan hasil kuesioner yang disebabkan kepada responden, maka dapat diketahui tanggapan responden tentang pengaruh pemberian kredit usaha rakyat terhadap perkembangan UMKM pada PT. Bank Papua Kantor Cabang Utama Jayapura. Analisis kuantitatif adalah data dalam bentuk angka-angka yang pembahasannya melalui perhitungan statistik berdasarkan jawaban kuesioner dari responden. Hasil perhitungan dari skor atau nilai tersebut kemudian dari statistik yang dilakukan dengan bantuan program SPSS untuk membuktikan hubungan pengaruh dari variabel-variabel penelitian.

\section{Hasil dan Pembahasan}

Hasil Penelitian

Statistik deskriptif Variabel Penelitian

Jumlah responden sebanyak 50

Tabel 2.

Descriptive Statistics

\begin{tabular}{llllll}
\hline Variabel & Minimum & Maksimum & Mean & Std. deviation & N \\
\hline X1 & 41,00 & 74,00 & 5,0600 & 7,56849 & 50 \\
Y1 & 44,00 & 85,00 & 68,0400 & 8,58085 & 50 \\
\hline
\end{tabular}

Sumber : data primer diolah 2019 


\section{Hasil Uji Validitas}

Pengujian validitas tiap item pertanyaan dilakukan dengan menghitung korelasi person product moment antara skor item dan skor total. Hasil uji validitas angket dengan menggunakan program SPSS 21.00 for windows adalah sebagai berikut :

Tabel 3.

Hasil Uji Validitas Variabel Pemberian Kredit Usaha Rakyat

\begin{tabular}{cccc}
\hline Item & rhitung & rtabel & Keterangan \\
\hline 1 & 0,696 & 0,284 & Valid \\
2 & 0,619 & 0,284 & Valid \\
3 & 0,574 & 0,284 & Valid \\
4 & 0,622 & 0,284 & Valid \\
5 & 0,619 & 0,284 & Valid \\
6 & 0,612 & 0,284 & Valid \\
7 & 0,555 & 0,284 & Valid \\
8 & 0,678 & 0,284 & Valid \\
9 & 0,809 & 0,284 & Valid \\
10 & 0,716 & 0,284 & Valid \\
11 & 0,711 & 0,284 & Valid \\
12 & 0,695 & 0,284 & Valid \\
13 & 0,448 & 0,284 & Valid \\
14 & 0,778 & 0,284 & Valid \\
15 & 0,514 & 0,284 & Valid \\
\hline
\end{tabular}

Sumber : data primer diolah 2019

Nilai rtabel untuk sampel taraf signifikan 0,05 adalah 0,284. Tabel 4.7 menunjukkan bahwa semua butir pernyataan tentang pemberian kredit usaha rakyat adalah valid, karena nilai $r$ hitung lebih besar dari $r$ tabel. Dengan demikian semua butir penyataan angket pemberian kredit usaha rakyat adalah valid.

Tabel 4.

Hasil Uji Validitas Variabel Perkembangan UMKM

\begin{tabular}{cccc}
\hline Item & rhitung & rtabel & Keterangan \\
\hline
\end{tabular}




\begin{tabular}{cccc}
\hline 1 & 0,894 & 0,284 & Valid \\
2 & 0,851 & 0,284 & Valid \\
3 & 0,678 & 0,284 & Valid \\
4 & 0,817 & 0,284 & Valid \\
5 & 0,705 & 0,284 & Valid \\
6 & 0,738 & 0,284 & Valid \\
7 & 0,769 & 0,284 & Valid \\
8 & 0,835 & 0,284 & Valid \\
9 & 0,734 & 0,284 & Valid \\
10 & 0,697 & 0,284 & Valid \\
11 & 0,806 & 0,284 & Valid \\
12 & 0,566 & 0,284 & Valid \\
13 & 0,849 & 0,284 & Valid \\
14 & 0,640 & 0,284 & Valid \\
15 & 0,474 & 0,284 & Valid \\
16 & 0,504 & 0,284 & Valid \\
17 & 0,656 & 0,284 & Valid \\
\hline
\end{tabular}

Sumber: data primer diolah 2019

Nilai rabel untuk sampel taraf signifikan 0,05 adalah 0,284. Tabel 4.8 menunjukkan semua butir pernyataan tentang perkembangan usaha mikro kecil dan menengah (UMKM) adalah valid, karena nilai rhitung lebih besar dari rtabel. Dengan demikian semua butir pernyataan angket perkembangan usaha mikro kecil dan menengah (UMKM) adalah valid.

\section{Hasil Uji Reliabilitas}

Uji reliabilitas dengan cara menghitung Cronbach's Alpha dari masingmasing instrumen dalam suatu variabel. Hasil uji reliabilitas masing-masing variabel adalah :

Tabel 5.

Hasil Uji Reliabilitas

\begin{tabular}{lcc}
\hline \multicolumn{1}{c}{ Variabel } & Cronbach's Alpha & Keterangan \\
\hline $\begin{array}{l}\text { Pemberian Kredit } \\
\text { Usaha Rakyat }\end{array}$ & 0,902 & Reliabel \\
Perkembangan UMKM & 0,942 & Reliabel \\
\hline
\end{tabular}

Sumber: data primer diolah 2019

Hasil pengujian reliabilitas terhadap variabel pemberian kredit usaha rakyat $(X)$ dengan variabel perkembangan UMKM (Y) Cronbach's Alpha sebagaimana terlihat pada tabel 4.9 menunjukkan bahwa nilai Cronbach's 
Alpha le bih besar dari 0,60 Oleh karena itu dapat ditentukan bahwa semua instrumen penelitian ini adalah reliabel.

\section{Hasil Uji Asumsi Klasik}

Sebelum uji hipotesis dilalkukan uji asumsi klasik terlebih dahulu untuk memastikan data memenuhi persyaratan di uji regresi. Uji asumsi klasik dalam penelitian ini meliputi: uji normalitas, multikolinearitas, heteroskedastisitas.

\section{Uji Normalitas}

Ghozali (2011:160) dalam penelitian ini akan digunakan uji one sample Kolmogorov smirnov dengan menggunakan taraf signifikansi 0,05. Data ini dinyatakan berdistribusi normal jika signifikansi lebih besar dari 0,05.

Tabel 6.

Hasil Uji Normalitas

\begin{tabular}{cccc}
\hline Variabel & $\begin{array}{c}\text { Kolmogorov- } \\
\text { Smirrov }\end{array}$ & $\begin{array}{c}\mathbf{p}- \\
\text { value }\end{array}$ & Keterangan \\
\hline $\begin{array}{c}\text { Unstandardized } \\
\text { Residual }\end{array}$ & 0,912 & 0,376 & $\begin{array}{c}\text { Sebaran data } \\
\text { normal }\end{array}$ \\
\hline
\end{tabular}

Sumber: data primer diolah 2019
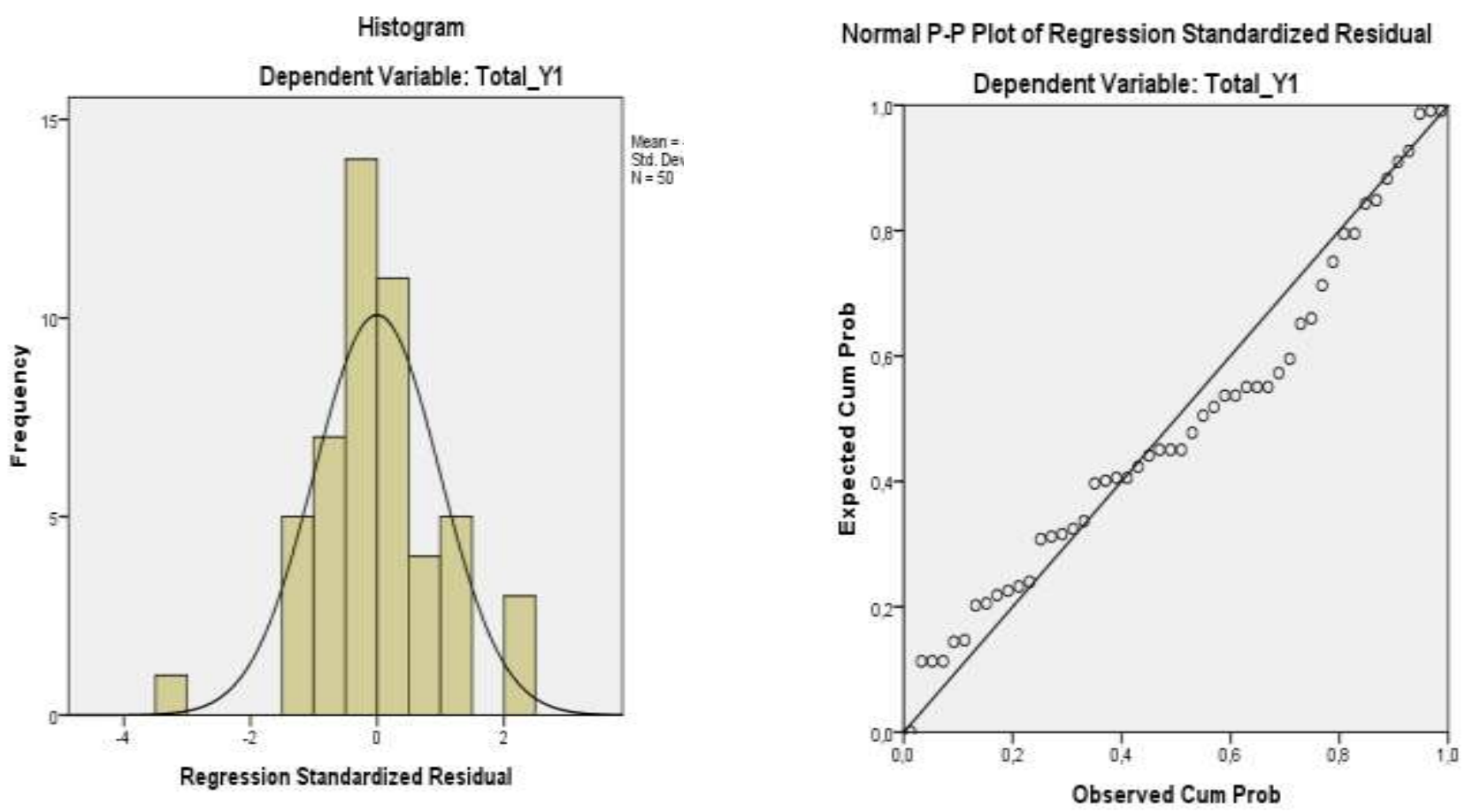

berdasarkan hasil uji Normalitas menggunakan metode kolmogorov Smirnov didapatkan hasil signifikan atau $p$ value sebesar 0,376 dimana hasil tersebut lebih besar dari taraf signifikansi 0,05. Sehingga dapat disimpulkan bahwa data berdistribusi normal dan memenuhi prasyarat uji asumsi klasik. 


\section{Uji Multikolinearitas}

(Ghozali, 2011) Dalam penelitian ini untuk menguji adanya multikolinearitas dilihat dari nilai VIF (Variance Inflation Factor) atau nilai tolerance. apabila nilai VIF $\geq 10$ atau tolerance value $\leq 0,10$. Maka dapat disimpulkan bahwa dalam penelitian tersebut terdapat multikolinearitas.

Tabel 7.

Hasil Uji Multikolinearitas

\begin{tabular}{lccl}
\hline \multicolumn{1}{c}{ Variabel } & $\begin{array}{c}\text { Toleranc } \\
\boldsymbol{e}\end{array}$ & VIF & Keterangan \\
\hline $\begin{array}{l}\text { Pemberian Kredit } \\
\text { usaha rakyat }\end{array}$ & 1,000 & 1,000 & $\begin{array}{l}\text { Bebas } \\
\text { multikolinearit } \\
\text { as }\end{array}$ \\
& & &
\end{tabular}

Sumber: data primer diolah 2019

Berdasarkan pada tabel 4.11 diatas dapat diketahui bahwa nilai VIF 1,000 dimana nilai tersebut lebih kecil dari 10 dan nilai tolerance 1,000 lebih besar dari 0,10. Dengan demikian dapat dinyatakan juga model regresi ini tidak terdapat masalah multikolinearitas.

\section{Hasil Uji Heteroskedastisitas}

(Ghozali, 2011), Pada penelitian ini akan diuji heteroskedastisitas menggunakan uji glesjer yaitu mengkorelasikan nilai absolut residual dengan masing-masing variabel.hasil dari uji glesjer menunjukkan tidak ada heteroskedastisitas apabila dari perhitunngan SPSS nilai probabiitas signifikansinya diatas tingkat kepercayaan $5 \%$.

Tabel 8.

Hasil Uji Heterokedastisitas

\begin{tabular}{lcc}
\hline \multicolumn{1}{c}{ Variabel } & p-value & Keterangan \\
\hline $\begin{array}{l}\text { Pemberian kredit } \\
\text { usaha rakyat }\end{array}$ & 0,057 & $\begin{array}{c}\text { Bebas } \\
\text { heterokedastisitas }\end{array}$ \\
\hline
\end{tabular}

Sumber: data primer diolah 2019

Berdasarkan hasil yang ditunjukan dalam tabel 4.12 diatas dapat diketahui bahwa nilai signifikansi variabel pemberian kredit usaha rakyat( independen) sebesar 0,057 lebih besar dari 0,05, sehingga dapat disimpulkan bahwa variabel independen tersebut bebas dari masalah heterokedatisitas. Dan memenuhi syarat uji asumsi klasik.

\section{Analisis Regresi Linear Sederhana}

Analisis ini digunakan untuk mengetahui pengaruh pemberian kredit usaha rakyat (X1) terhadap perkembangan usaha mikro kecil dan menengah (Y1). Hasil pengolahan data dengan bantuan komputer program SPSS versi 21 didapatkan persamaan regresi ditunjukkan dalam bentuk tabek berikut: 
Tabel 9.

Hasil Uji Regresi Linear Sederhana

\begin{tabular}{lcccc}
\hline \multicolumn{1}{c}{ Variabel } & $\begin{array}{c}\text { Koef. } \\
\text { Regresi }\end{array}$ & thitung & Sig & $\begin{array}{c}\text { Keteranga } \\
\mathrm{n}\end{array}$ \\
\hline Konstanta & 23,197 & 3,417 & 0,001 & \\
\hline $\begin{array}{l}\text { Pemberian Kredit } \\
\text { usaha Rakyat (X1) }\end{array}$ & 0,786 & 6,663 & 0,000 & Signifikan \\
\hline R adjusted square & 0,470 & & \\
\hline \multicolumn{4}{r}{ Sumber : data primer diolah 2019}
\end{tabular}

Hasil analisis regresi linier sederhana seperti pada tabel 4.13 di atas dapat ditulis persamaan regresi yaitu sebagai berikut:

$\mathrm{Y}=23,197+0,786 \mathrm{X}$

Nilai konstanta sebesar 23,197 hal ini berarti bahwa perkembangan usaha mikro kecil dan menengah akan sebesar 23,197 jika pemberian kredit usaha rakyat sama dengan nol. Hal ini dapat dijelaskan bahwa perkembangan usaha mikro kecil dan menengah akan menurun jika tidak ada pemberian kredit usaha rakyat.

Variabel pemberian kredit usaha rakyat (X1) mempunyai pengaruh positif terhadap perkembangan usaha mikro kecil dan menengah (UMKM), dengan koefisien regresi sebesar 0,786 menunjukkan bahwa apabila perkembangan usaha mikro kecil dan menengah meningkatkan sebesar 1 persen maka pemberian kredit usaha rakyat akan meningkat sebesar 0,786 persen dengan asumsi variabel bebas konstan. Nilai signifikan (sig) sebesar 0,000 nilai ini jauh lebih rendah dibandingkan dengan 0,005 maka pengaruh pemberian kredit usaha rakyat terhadap perkembangan usaha mikro kecil dan menengah adalah signifikan.

Berdasarkan perhitungan SPSS, nilai thitung sebesar 6,663 sedangkan $p$ value sebesar 0,000 sehingga $p$ value $<5 \%(0.000<5 \%)$, artinya ada pengaruh signifikan variabel pemberian kredit usaha rakyat terhadap perkembangan usaha mikro kecil dan menengah. Hasil ini menunjukkan bahwa semakin tinggi pemberian kredit usaha rakyat maka perkembangan usaha mikro kecil dan menengah akan semakin baik, begitu pula sebaliknya.

Koefisien determinasi R2 sebesar 0,470 yang berarti 47,0\% variasi pada variabel dependen perkembangan usaha mikro kecil dan menengah dapat dijelaskan dengan variabel independen pemberian kredit usaha rakyat. Sementara sisanya yaitu sebesar $53,0 \%$.

Dengan demikian pemberian kredit usaha rakyat berpengaruh positif terhadap perkembangan usaha mikro kecil dan menengah (UMKM) pada PT. Bank Papua Kantor Cabang Utama Jayapura. 


\section{Uji Hipotesis}

Uji $t$

Uji t digunakan untuk menguji pengaruh variabel bebas (independen) terhadap variabel tidak bebas (dependent) secara terpisah atau sendiri-sendiri. Berdasarkan hasil analisis dapat diketahui hasil uji $t$ ditunjukkan sebagai berikut:

Tabel 10.

Hasil Uji t

\begin{tabular}{|c|c|c|c|c|c|}
\hline \multirow[t]{2}{*}{ Model } & \multicolumn{2}{|c|}{ Unstandardized Coefficients } & \multirow{2}{*}{$\begin{array}{c}\text { Standardi } \\
\text { zed } \\
\text { Coefficien } \\
\text { ts }\end{array}$} & \multirow[t]{2}{*}{$\mathrm{T}$} & \multirow[t]{2}{*}{ Sig. } \\
\hline & B & Std. Error & & & \\
\hline \multirow[b]{2}{*}{ Total_X1 } & 23,197 & 6,788 & & 3,417 & 001 \\
\hline & ,786 & ,118 & 693 & 6,663 & 000 \\
\hline
\end{tabular}

Sumber : data primer diolah 2019

Dari hasil tabel 4.14 untuk menguji apakah hipotesis yang diajukan diterima atau ditolak, maka perlu diuji coeffisien dengan melihat thitung. Jika thitung < ttabel ,maka Ho diterima, tidak ada pengaruh variabel bebas terhadap variabel tidak bebas. Nilai ttabel dengan menentukkan taraf nyata 5\% maka diperoleh nilai ttabel sebesar 2,011. Dalam perhitungan tabel di atas diperoleh: Variabel pemberian kredit usaha rakyat, $t$ hitung 6,663 > t tabel 2,011 dengan demikian H1 diterima dan Ho ditolak, sehingga dapat disimpulkan bahwa pemberian kredit usaha rakyat berpengaruh terhadap perkembangan usaha mikro kecil dan menengah (UMKM) di Kota Jayapura.

\section{Pembahasan Hasil Penelitian}

Sesuai dengan rumusan dan tujuan penulisan yang telah penulis tetapkan, maka berikut ini adalah uraian pembahasan dari hasil analisa data sebagai berikut:

Pengaruh Pemberian Kredit Usaha Rakyat (KUR) Terhadap Perkembangan Usaha Mikro Kecil dan Menengah (UMKM) di Kota Jayapura

Penyaluran KUR diatur oleh pemerintah melalui menteri keuangan NO. 135/PMK.05/2008 tentang fasilitas penjaminan Kredit Usaha Rakyat yang telah diubah dengan peraturan menteri keuangan No. 10/PMK.05/2009.

Optimalisasi penyaluran Kredit Usaha Rakyat bagi pembiayaan UMKM. Optimisme pemberdayaan usaha mikro, kecil dan menengah (UMKM) adalah optimisme membangun kembali perekonomian bangsa yang lebih kokoh. Peran sektor ini sendiri sangat dominan dalam perekonomian nasional terbukti 
peran sector UMKM semakin besar Dalam perekonomian nasional dari tahun 2010, dimana UMKM mampu meraih 30,4\% dari PDB mikro, kecil, dan menengah dipengaruhi secara signifikan oleh GDP,suku bunga kredit, kapasitas kredit dan NPL, dimana GDP berpengaruh positif sedangkan suku bunga kredit, kapasitas kredit dan NPL berpengaruh negatife.

Variabel pemberian kredit usaha rakyat merupakan variabel yang berpengaruh secara parsial terhadap perkembangan usaha mikro kecil dan menengah (UMKM) di Kota Jayapura. Hasil perhitungan statistika diketahui nilai $t$ hitung 6,663 dan $t$ tabel 2,011 atau $t$ hitung $>t$ tabel $(6,663>2,011)$, hal ini berarti variabel pemberian kredit usaha rakyat merupakan variabel yang berpengaruh signifikan terhadap perkembangan usaha mikro kecil dan menengah (UMKM) di Kota Jayapura.

Hasil penelitian tersebut menerangkan bahwa perkembangan usaha mikro kecil dan menengah (UMKM) dipengaruhi oleh suatu pemberian kredit usaha rakyat untuk menjalankan usahanya. Hal tersebut didasarkan pada pengalaman para pelaku UMKM pada sebelumnya, pelaku UMKM berpendapat bahwa dengan mengambil kredit dilakukan untuk menambah harta atau aset dan menambah modal usaha dan juga dapat meningkatkan perkembangan usaha yang dijalankan.

(Pratama Putra \& Setyadhi Mustika, 2012) melakukan pengamatan terhadap program yang di gulirkan oleh pemerintah melalui lembaga Jamkrida. Jamkrida memberikan jaminan kredit bagi UMKM dalam upaya membantu permodalan untuk kelangsungan dan pengembangan usaha dimasa yang akan datang. Tujuan penelitian untuk mengetahui efektivitas program Jaminan Kredit Daerah (jamkrida) di kabupaten tabanan, penyerapan tenaga kerja UMKM di Kabupaten Tabanan. Sampel penelitian ditentukan dengan rumus slovin sebanyak 76 UMKM.

Dari penjelasan diatas dapat disimpukan bahwa perkembangan Usaha Mikro Kecil dan Menengah sebagian besar dipengaruhi oleh pemberian kredit usaha rakyat (KUR) yang diberikan dari PT. Bank Papua untuk para pelaku UMKM.

\section{Kesimpulan}

Kredit Usaha Rakyat (KUR) merupakan salah satu program pemerintah yang dianggap dapat mengatasi masalah permodalan bagi UMKM, pemerintah memberikan akses kredit usaha rakyat atau sering dikenal dengan KUR tersebut melalui lembaga perbankan yang pada saat ini sangatlah berperan baik. Kredit Usaha Rakyat (KUR) pada Bank Papua adalah kredit yang tergolong dalam kredit modal kerja yang diperuntukkan untuk pertambahan modal bagi usaha mikro kecil dan menengah. Kredit ini memberikan dana pinjaman perseorangan maksimal Rp.25.000.000 dan untuk badan usaha 
maksimal sebesar Rp. 500.000.000. Ketentuan pengajuan Kredit Usaha Rakyat ialah calon debitur tidak mempunyai kredit KUR di bank lain tidak termasuk dalam golongan kredit macet,usaha berjalan minimal 6 bulan.

Prosedur pengkreditan meliputi ketentuan dan syarat atau yang harus dilakukan sejak nasabah mengajukan permohonan kredit sampai kredit dilunaskan oleh nasabah. Syarat dan ketentuan sebagai berikut :

1. Sudah menjadi nasabah bank papua tersebut

2. Mengajukan proposal/ surat permohonan kredit secara tertulis kepada Bank Papua dengan informasi.

a. Jenis pembiayaan

b. Tujuan pembiayaan

c. Jangka waktu kredit

d. Agunan/jaminan kredit

e. Nilai agunan minimal $100 \%$ dari nilai likuidasi kredit

3. Legalitas badan usaha

a. Fotocopy akta pendirian perusahaan

4. 4. Legalitas operasional

a. Fotocopy KTP

b. Fotocopy surat ijin usaha tempat usaha(SITU)

c. Fotocopy surat ijin usaha perdagangan (SIUP)

d. Fotocopy NPWP, SPT tahunan (terakhir)

e. Fotocopy tanda daftar perusahaan (TPD)

f. Fotocopy surat ijin jasa konstruksi (SIUJK)

g. Fotocopy kartu keluarga, surat nikah pemohon

h. Pas foto debitur $4 \times 6$ sebanyak 2 lembar bersama pasangannya untuk kredit usaha (perorangan).

i. Pas foto debitur untuk perusahaan yang berbadan hukum

5. Struktur organisasi

a. Fotocopy jaminan Kredit (asli setelah disetujui).

b. Fotocopy jaminan kredit milik sendiri (diutamakan)

c. Fotcopy sertifikat tanah, IMB dan pembayaran IBB/NJOP

d. Fotocopy faktur alat berat/invoice

e. Fotocopy PBBNJOP

f. Laporan keuangan terbaru (neraca dan laba/rugi), paling lama dua bulan terakhir dan atau yang telah diaudit oleh KAP

6. Ketentuan Lain

a. Plafond KUR Mikro Maksimal Rp. 25.000.000

b. Plafond KUR Ritel Maksimal Rp. 500.000 .000

Pemberian Kredit Usaha Rakyat (KUR) berpengaruh signifikan secara parsial terhadap Perkembangan Usaha Mikro Kecil dan Menengah di kota Jayapura. Hal tersebut dapat dilihat dari lebih besarnya nilai t-hitung variabel 
bebas dibandingkan nilai t-tabel, dengan nilai t-hitung variabel Pemberian Kredit Usaha Rakyat $=6,663$ lebih besar dari nilai t-tabel =2,011. Artinya bahwa perkembangan UMKM di kota Jayapura tergolong baik. Terdapat pengaruh antara variabel pemberian kredit usaha rakyat terhadap perkembangan usaha mikro kecil dan menengah (UMKM) di kota Jayapura. Ditunjukkan dengan persamaan regresi linier sederhana $\mathrm{Y}=23,197+0,786 \mathrm{X}$. berdasarkan pada pengujian koefisien determinasi R2 sebesar 0,470, artinya besaran kredit mempengaruhi perkembangan usaha $47,0 \%$ dan sisanya sebesar $53,0 \%$ dipengaruhi oleh variabel-variabel lain yang tidak dibahas dalam penelitian.

\section{Bibliografi}

Anggraini, D., \& Nasution, S. H. (2013). Peranan kredit usaha rakyat (KUR) bagi pengembangan UMKM di Kota Medan (studi kasus Bank BRI). Ekonomi Dan Keuangan, 1(3).

Arliman, L. (2017). Perlindungan hukum UMKM dari eksploitasi ekonomi dalam rangka peningkatan kesejahteraan masyarakat. Jurnal Rechts Vinding: Media Pembinaan Hukum Nasional, 6(3), 387-402.

Darwanto, D. (2013). Peningkatan Daya Saing UMKM Berbasis Inovasi dan Kreativitas (Strategi Penguatan Property Right terhadap Inovasi dan Kreativitas). Jurnal Bisnis Dan Ekonomi, 20(2), 24200.

Ghozali. (2011). Aplikasi Analisis Multivariate dengan program SPSS. Badan Penerbit Universitas Diponegoro.

Hamidu, N. P. (2013). Pengaruh kinerja keuangan terhadap pertumbuhan laba pada perbankan di BEI. Jurnal EMBA: Jurnal Riset Ekonomi, Manajemen, Bisnis Dan Akuntansi, 1(3).

Pratama Putra, G. S., \& Setyadhi Mustika, M. D. (2012). Efektivitas Program Jamkrida dan Dampaknya terhadap Pendapatan dan Penyerapan Tenaga Kerja UMKM. EJurnal Ekonomi Pembangunan Universitas Udayana, 3(12), 44493.

Saputro, J. W., Handayani, P. W., Hidayanto, A. N., \& Budi, I. (2010). Peta rencana (roadmap) riset Enterprise Resource Planning (ERP) dengan fokus riset pada Usaha Kecil dan Menengah (UKM) di Indonesia. Journal of Information Systems, 6(2), 140-145.

Sedyastuti, K. (2018). Analisis Pemberdayaan UMKM dan Peningkatan Daya Saing Dalam Kancah Pasar Global. INOBIS: Jurnal Inovasi Bisnis Dan Manajemen Indonesia, 2(1), 117-127.

Supriyanto. (2006). Pemberdayaan usaha mikro kecil dan menengah (UMKM) sebagai salah satu upaya penanggulangan kemiskinan. Jurnal Ekonomi Pendidikan., 3(1), 116.

Wahyuni, Eti, D. (2005). Lilitan Masalah Usaha Mikro, Kecil, Menengah (UMKM) E Kontroversi Kebijakan. BITRA Indonesia. 